Ellen Redling

\title{
New Plays of Ideas and an Aesthetics of Reflection and Debate in Contemporary British Political Drama
}

\begin{abstract}
In recent years a number of British plays, especially political dramas, have been laying emphasis on argumentation and reflection rather than quick action. This is particularly the case when complex national or global political issues are addressed. This article argues that since the late 1990s a new drama of ideas has taken the stage and created a "thinking place" within the "viewing place," the theatron. It looks at current dramatic, politico-philosophical and cultural contexts surrounding the concepts of reflection and debate which point to a revival of deliberative processes and a renewed interest in big questions regarding, for example, the military, the economy, the environment, health and multi-ethnicity. These contexts can be connected to the emergence of new plays of ideas. At the same time, the essay examines strategies that can be used to aestheticise the notions of reflection and debate in such dramas and to move them to the forefront in terms of, for instance, relativising ideologies, adding challenging figures as 'audiences' to the debate and fusing personal matters with ideas. Examples of a focus on reflection and debate can be found in Joe Penhall's Blue/Orange (2000), Lucy Prebble's Enron (2009), D.C. Moore's The Empire (2010) and Duncan Macmillan's Lungs (2011).
\end{abstract}

Keywords: New plays of ideas, aesthetics, reflection, debate, deliberative democracy

Ellen Redling: E-Mail: ellen.redling@as.uni-heidelberg.de

\section{The Emergence of New Plays of Ideas}

Since the late 1990s and early 2000s the works of a number of British playwrights have focused on big ideas and foregrounded reflection and debate rather than quick action. In some cases these include plays written by older writers like the left-leaning David Hare, who for decades has been an issue-oriented playwright. ${ }^{1}$

1 Cf. David Hare's Stuff Happens (2004) and The Vertical Hour (2006). 
However, what is crucial now is that works by younger authors such as Lucy Prebble, D.C. Moore, Duncan Macmillan and Joe Penhall, who are in their thirties and forties, are also displaying an approach of reflection and debate. ${ }^{2}$ There are some differences in style - since Prebble's drama Enron (2009), for instance, combines musical and multi-media elements with dialogue while the other plays are mostly based on dialogue - but debates on different ideas can be seen to stand at the centre of all of these plays. The ideas presented in these and other plays $^{3}$ stem from a variety of fields such as politics in a narrow sense of the term, the military, the economy, the environment, health and multi-ethnicity. If, however, an extended sense of politics that includes the economy and society applies, these various plays could be grouped together under the heading "political plays." Frequently, such dramas treat moral problems within their respective field such as the question of responsibility regarding the credit crunch in 2008.

Reasons for this emergence of new plays of ideas can be found in the history of drama itself as well as in recent cultural and political developments in Western societies. In terms of dramatic trends, the spectacular violence depicted in the "in-yer-face" plays of the 1990s (cf. Sierz, In-Yer-Face Theatre) might, with its selfexhaustion, have given way to quieter dramas. This change would support the perspective that tendencies in literary history are frequently followed by countertendencies. For instance, Mark Ravenhill's play Mother Clap's Molly House (2001) inserts a discussion of ideas, that is of serious moral questions related to homosexuality, rather than completely continuing the trend of an "in-yer-face" play like his Shopping and Fucking (1996). On the other hand, the decrease in strict oppositions of ideologies such as capitalism vs. socialism after the fall of the Soviet Union, as well as a general increase in pluralism, which arguably picked up speed through the rise of the new media in the 2000s, may have encouraged various dramatists to probe what big ideas are worth discussing now. In other words, since an over-emphasis on pluralism can be seen as standing in the way of discussions of big ideas, due to a focus on small details and petits récits, we could now be witnessing a counter-movement towards larger issues again. As capitalism is still with us, the new epoch might have opened up space for serious debates in drama concerning, for example, the growing mercantile nature of many areas of Western societies or legal and moral abuses of money, power, justice and freedom.

2 In Rewriting the Nation: British Theatre Today, Aleks Sierz also draws attention to the fact that plays by newer voices like Matt Charman, Fin Kennedy and Ryan Craig address ideas (cf. 57).

3 This article is part of the initial work on my much larger post-doctoral project which has the working title "New British Plays of Ideas." 
A favourable climate for drama was created by the change from the Thatcher era to the New Labour government in 1997. As Aleks Sierz writes, "Under New Labour, theatre got more money than ever before" (Rewriting the Nation 1). Regarding political plays, the fact that when Tony Blair took office he did not renationalise industries or services as earlier Labour governments had done, as well as the fact that his government later participated in the war in Iraq have given rise to political dramas that deal with these issues.

In the context of new plays of ideas it is important to note that the act of discussing big issues itself and the question of who should take part in such a debate are also currently receiving wider attention in Western cultures and politics. Interest in participatory politics such as deliberative democracy has been experiencing a revival since the late 1990s. ${ }^{4}$ As James Fearon makes clear, greater deliberative democracy means that more ordinary citizens are "brought into a richer conversation about public policy and politics" (63). In such a form of democracy careful deliberation "among free, equal, and rational agents" (Elster 5) is used to form a common will, ${ }^{5}$ which can give political decisions a higher degree of legitimacy. Deliberation here can involve the idea of ordinary people thinking for themselves rather than handing over responsibilities to others unquestioningly.

An over-reliance on others was precisely a problem in the 2000s, when the complexity of the financial markets created obscurity and often led to a blind belief in false 'guru'-like expert figures. As John Lanchester aptly puts it, "the free market [...] became an item of faith, or near mystical belief. In that belief system, the finance industry made up the class of priests and magicians, and began to be treated as such" (13). Lucy Prebble's play Enron (2009) can be read as depicting such a 'guru'-like figure: Jeffrey Skilling, CEO of the American energy giant Enron, which notoriously collapsed in 2001 due to its enormously fraudulent practices. ${ }^{6}$ The play can signal that a warning such as the Enron scandal was ignored early on - an attitude of neglect or complete indifference which probably contributed to the great financial crisis in 2008.

In many ways, there now is a particular public interest in questioning the responsibilities of politicians, church officials, company owners and other 'global

4 Jon Elster points out: "The idea of deliberative democracy [...] is having a revival. [...]. Largely under the influence of Jürgen Habermas, the idea that democracy revolves around the transformation rather than simply the aggregation of preferences has become one of the major positions in democratic theory" (1).

5 Cf. also Habermas, Between Facts and Norms 320.

6 For further information regarding such fraudulent financial actions and the play Enron cf. McDowell. 
players' through debate rather than mere protest. ${ }^{7}$ A desire for a greater involvement of the 'lower ranks' can also be seen in Western economies. Companies for instance in the IT sector - are now wondering how to best devise clever, creative solutions and are increasingly breaking up hierarchies and adopting bottom-up strategies rather than top-down ones. ${ }^{8}$ Political life may therefore not be completely characterised by what Amelia Howe Kritzer describes as "public disengagement and detachment" (26). Though perhaps not fully developed, there are certain tendencies that share some common ground with the movement towards Kant's sapere aude during the Age of Enlightenment. ${ }^{9}$ This questioning attitude in turn indicates that a period of misguided beliefs such as the trust in the financial markets in the 2000s gives way to a time of reason(ing). In this regard it may therefore not be a coincidence that Mark Ravenhill chose to present a dramatic version of Voltaire's Candide in 2013.

Some plays, like Blue/Orange (2000) by Joe Penhall, who is known for his argumentative style, ${ }^{10}$ can even be said to draw attention to a need for deliberative processes and for an openness of discussion itself. Interestingly, the play is set in a hospital context where strict hierarchies are in place and older doctors clash with younger ones. Deliberative processes, however, largely call for a breaking up of such hierarchies. In the drama, two doctors, the senior consultant Robert and the younger doctor Bruce, disagree over the best method of treating Christopher, a mentally ill patient of African descent. Bruce, a seeming idealist, wants to have time to reach a proper diagnosis. He is in favour of careful discussion and is focused on the single patient rather than on textbook theories. His superior Robert, however, is a manager-type doctor. He likes to take "the path of least resistance" (25) and dislikes the fact that his subordinate, Bruce, "think[s] too much" (50).

Robert initially seems to be the only one standing in the way of a fruitful discussion. However, in the course of the play it emerges that both doctors hamper a process which can be regarded as deliberation. They both turn out to be motivated by self-interest. Robert, who wants to use the patient's release to prove

7 See, for instance, the discussions provoked by the alleged use of taxpayer money for private purposes by a number of both British and German politicians, or by German Bishop Tebartz-van Elst's mishandling of church money. The NSA scandal could also be taken into account, and many other both national and transnational examples could be added to this list.

8 Cf., for example, Stephen O'Grady's The New Kingmakers: How Developers Conquered the World (2013).

9 Movements towards greater participation in politics such as deliberative democracy are frequently linked to Enlightenment ideas - e.g. by Jürgen Habermas. Cf. Calhoun et al. $444 \mathrm{ff}$.

10 Cf. William C. Boles's The Argumentative Theatre of Joe Penhall (2011). 
his own culture-related theory, seeks to bargain with Bruce and even threatens him. If Bruce wants to move up a step in his career, he should, as Robert puts it, "play the game" (24) and adhere to the wishes of authorities like himself rather than cause trouble by thinking of treatments that cost money and time. Bruce, in turn, becomes overly obsessed with the idea of keeping the patient in the hospital. In the final act of the play, Christopher - due to the instigations of Robert accuses Bruce of being "racist” (83). But Bruce lodges counter-charges against Robert. The legal battle with which the play ends obviously does nothing to help the patient. A meaningful discussion is no longer possible. The play can be read as a call for greater deliberation or even deliberative democracy - in the sense of a discussion which includes people of lower professional status and even the patient himself. At the same time the drama presents reasons for the breakdown of such a debate.

The increasing neglect of Christopher's well-being in Blue/Orange together with the failure of the discussion process can also signal a wish for more morallyoriented debates on big issues outside the theatre. Such a desire can be linked to observations made by the political philosopher Michael Sandel, who points out that there is currently still too little lasting moral argument on big issues in political as well as in public life (cf. What Money Can't Buy 13). Sandel especially refers to his own country, the United States, but suggests that such a lack of moral debate is a problem common to all Western market-oriented societies, where for the last two to three decades the focus on a market rationale, on money and consumerism has been increasingly "crowding out" discussions about meaningful social and political issues such as: "income and wealth, duties and rights, powers and opportunities, offices and honors" (Justice 19). In his most recent work, What Money Can't Buy: The Moral Limits of Markets (2012), Sandel argues that it is high time to think again about the ancient great question of "how we want to live together" (203) and about how we want to deal with civic duties, virtues and values in a world dominated by market thinking. In another study, called Justice: What's The Right Thing To Do? (2009), he describes various examples of how the burden of such duties and virtues, which should ideally be shared by the entire society, is increasingly placed on those who have almost no choice but to carry it for everybody else. One of these examples is the concept of a volunteer army. Sandel asks whether or not such an army is really voluntary: "Is there a reasonable degree of equal opportunity, or do some people have very few options in life?" (81f.). His suggestion is that "military service is not just another job; it's a civic obligation" (82) and he compares it to jury duty in the US, which also cannot be simply transferred to somebody else (cf. 85).

Regarding the civic duty of military service, the English writer D.C. Moore's drama The Empire (2010) shares some similarities with Sandel's army example. 
The play can thus be read as depicting a debate which might not yet be sufficiently taking place in the political or public world outside the theatre. The drama is set in a hovel in the Helmand Province of Afghanistan in 2006 - during the war in Afghanistan. In this hut, the British soldier Gary is watching someone whom he thinks is a wounded and unconscious Taliban fighter and whom he holds responsible for the death of his best friend Phipps earlier that day. The play takes an unexpected turn when the fighter - who is called Zia - awakes and claims that he is not a Talib but a normal British citizen kidnapped by the Taliban and dressed to look just like them. However, Gary is not prepared to listen to his explanations. This disbelief seems to be connected to the fact that Zia reminds Gary of what he rudely refers to as the "brown cunts" (88), i.e. the Asian immigrants he went to school in England with. Suddenly, the battle scene in Afghanistan conceptually begins to merge with school as well as class struggles in England. Gary points out to his superior, Simon, that the latter surely did not go to a similar school with lots of immigrants. Moreover, a blending of time sets in as Gary links this current battle to conflicts that happened during the British Empire:

GARY. Yeah, way it is. Like. My dad. He's an old fucker. He was in Aden. Doing shit like this. For cunts like you. And my grandad. India. And it's. Thick cunts, led by posh cunts, hitting brown cunts. Way it is. Even now. (88)

Gary seems to be implying that he can simply take revenge for all the wrongs done to him in the past and the present, and that he can repeat history and is even justified in doing so. But the sudden levelling use of the expletive "cunts" for three different social groups (working class, upper class and immigrants/the colonised), which diverges from the earlier singling out of "cunts like [Zia]" (87), can also suggest that this is a useless battle that simply repeats the past, with "posh cunts" dominating over "thick cunts," who in turn "hit" "brown cunts." The expletive, now signifying something like 'poor sods' or 'poor mates,' therefore would indicate a feeling of solidarity in this war and level differences. Revenge can be interpreted as becoming the wrong anti-thesis. Seen in this way the play not only deals with the problem of current military intervention abroad. It also poses crucial questions regarding class issues in England and the civic question of who fights England's wars and why. Aside from reflecting wishes for debate and deliberation, new plays of ideas can therefore also show or even anticipate discussions which are perhaps not yet sufficiently occurring in political or public contexts outside the theatre. 


\section{Aestheticising Reflection and Debate in Contemporary British Political Drama}

New plays of ideas appear to diverge from earlier ones, e.g. the dramas written by Henrik Ibsen and George Bernard Shaw, ${ }^{11}$ in that they can be much more ambiguous as to what the 'right' idea is. Various options may be presented and it is then up to the viewer to decide which could be the more preferable one. Nevertheless, a strong emphasis on reflection and debate is present in contemporary dramas of ideas just as it was in older ones. It is important to note that debate in this context does not mean a simple functional discussion about advantages and disadvantages regarding a certain point, which might be led outside the theatre. In plays of ideas one can find heightening and thus dramatising strategies which are added to the topicality of the discussions and thereby also aestheticise the processes of reflection and debate themselves.

Some of these dramatising techniques can already be found in Plato's Socratic dialogues, which can be read as early 'dramas' of ideas. Plato's ideas, which, for instance, deal with metaphysical questions, are stricter than those found in Ibsen and Shaw. They are envisaged as being completely constant, timeless and fixed. For this reason they are perhaps ideally looked at without any consideration of context at all, as completely abstract. However, this is difficult to put into practice since humans are usually influenced by the precise time and place which they find themselves in. Plato interestingly makes dramatic use of this dilemma. In the dialogue Phaedo, Socrates is about to face death by drinking hemlock and is surrounded by his students, his fictional 'audience,' who react fearfully to the imminent death of their admired and beloved teacher. Socrates meanwhile discusses with them that the soul lives on after death and that therefore his body is not important, meaning that the students should not be sad. The students are not easily convinced. They live in the here and now - rather than on an abstract level. Their personal concerns become mixed with the greater question of the immortality of the soul. The dramatic addition of an 'audience' and their difficulties therefore both complicates and dramatises Socrates's ideas. ${ }^{12}$ Through their dramatisation the ideas can become more appealing and accessible to real-life recipients.

11 Cf., for example, Ibsen's A Doll's House (1879) and Shaw's Man and Superman (1902-03) as well as Pygmalion (1912-13). There is a renewed interest in these older plays of ideas, as Simon Stephens's 2012 version of $A$ Doll's House shows.

12 On the dramatic use of an audience in Plato, cf. also Puchner 26-30. 
The technique of adding a fictional 'audience' and their problems to the discussion of ideas can also be found in contemporary British drama - for instance in Penhall's Blue/Orange - where it can reflect a topical concern with deliberative processes. Bruce's and Robert's debate is arguably made more difficult by the younger doctor's sceptical attitude, as well as by the presence of the erratic patient Christopher, who may or may not be seriously mentally ill, ${ }^{13}$ whose situation is potentially influenced by cultural factors, who changes sides quickly and who finally - with Robert's help - lodges a complaint of racism against Bruce. This strategy of including 'audience' figures highlights and heightens the difficulties in what might otherwise simply be a functional debate about advantages and disadvantages of an in-house treatment of mentally ill and culturally diverse patients.

Aside from 'audience' figures, one can also find a dramatic use of time in Plato's Phaedo. Since the dialogue starts out with general discussions about the immortality of the soul and then gets increasingly specific regarding Socrates's approaching death, time seems to speed up towards the end of the debate, which augments the dramatic fear of the students. A comparable use of time can be seen in Duncan Macmillan's play Lungs (2011). The drama begins with wide-ranging discussions. A man and a woman, who have the unspecific names $\mathrm{M}$ and $\mathrm{W}$, speak about the difficulties connected to having a baby in a time of over-population and climate change. The woman is initially more concerned about the environment than the man. She claims: "I could fly to New York and back every day for seven years and still not leave a carbon footprint as big as if I have a child" (50), while the man points out that there might be "a lot of scaremongering" (51) regarding this issue. But the man soon changes his opinion and suggests: "I think we should plant trees. The company. Lots of them. Forests of them. Try to offset [...] our footprint" (53). They seem to have time to think - both about the environmental situation and about the future baby. However, as the play progresses and a pregnancy actually occurs, time is compressed and more and more personal issues - including miscarriage, betrayal, temporary separation, successful pregnancy and marriage - are added to the larger discussion. These issues increasingly divert attention away from environmental problems and result in a very narrow focus on the couple and their fears. The personal anxieties in turn lead to fights rather than discussions (cf. 64) and hasten their own 'decay' as well as, interestingly, that of the world. The play ends with solitude in old age and an apocalyptic scenario. W says to her presumably dead husband: "Here I am talking

13 As Margarete Rubik points out, Robert's explanation of Christopher's behaviour "destabilises our conviction that such idiosyncrasy must necessarily be a sign of madness” (370). 
to myself. Your forests have gone. I don't watch the news any more, it all just gets worse and worse" (104). The compression of time therefore dramatises the debate in the sense that the couple become overly involved with their own personal fears instead of the wider perspective. This development can draw attention to a contemporary urgent need for taking time to reflect on and discuss larger issues like climate change.

Another aestheticising technique which appears in Plato's Socratic dialogues is the use of ambivalent language which calls for clarification. In the dialogue Ion Socrates and the rhapsode Ion discuss the question of what 'real' art, téchnē, is and whether it is to be found in poetic works. The problem hinges on the exact meaning of téchnē, which usually signifies practical or technical knowledge rather than unsubstantial visions. A similar instance of linguistic ambiguity can be seen in Moore's The Empire, where the levelling use of the expletive "cunt" contrasts with the earlier disparaging reference to "cunts like [Zia]" and can therefore signal a feeling of solidarity rather than revenge. This case of ambivalent language can also indicate topicality aside from pointing back to Plato, since a complex usage of obscene language may clash with current expectations about rough military language and also differs from a shocking use of expletives in the "in-yer-face" plays of the 1990s. ${ }^{14}$

There are, of course, also aestheticising techniques which are recent creations. One of these is the use of the rhetoric of advertising which can be connected to our modern-day mercantile world. This becomes apparent in Lucy Prebble's Enron. The play depicts discussions of ideas between Jeffrey Skilling, CEO of Enron, and the character of Claudia Roe, Enron executive. Roe is in favour of a locally-oriented business which sells the actual good of power and cares for its employees, while Skilling takes the market to a virtual level and loses sight of the needs of his employees. Various critics have focused on the protagonist Jeffrey Skilling as a classical tragic hero who is brought down by his hubris. ${ }^{15}$ However, he seems to resemble a 'guru' or spin doctor who tries everything to sell his concepts, rather than coming across as a tragic character. Braggart figures and tricksters are well known in literary history, but Skilling evangelises his ideas and company in a very modern flashy and commercial manner, which can dramatise the discussions of ideas:

SkILLING. Ladies and Gentlemen, Enron is a new kind of company. You want to see the next big thing? It's in the minds of one of these people. We're not just an energy company, we're

14 Sierz describes the use of "filthy" language as part of the "shock tactics" of "in-yer-face" plays (In-Yer-Face Theatre 5).

15 Cf., for example, Spencer, and McDowell. 
a powerhouse for ideas. No other company lets people work as freely and creatively as we do. (32)

When his company fails, Skilling, unlike a tragic hero, does not give in at the end. Instead, he remains defiant. Justice or moral turn-around do not appear to be the final chords of the play. The audience is more likely shocked by his praise of his own brilliance up until nearly the very end; it is only then that Skilling allows for some mistake. Nevertheless, he still boasts about his creativity and greatness, which suggests a continuation of his commercial language beyond the scope of the play. Since there is no catharsis, this open ending may in turn lead to further reflection.

To conclude, this article has discussed dramatic, politico-philosophical and cultural contexts that can be linked to concepts of reflection, debate and deliberation and to an emergence of new plays of ideas since the late 1990s. In a second step, various methods were looked at which can involve the audience of such plays in an aesthetic experience. Since dramas of ideas might be prone to create boredom - featuring as they often do protracted debates - they require the use of techniques that dramatise the discussions of ideas and thereby go beyond mere functionality. These techniques include, for instance, adding an extra character who challenges the underlying motivations of the protagonists, fusing personal issues with ideas, compressing time, using ambivalent language or employing commercial rhetoric in a thought-provoking way. The emergence of new plays of ideas and, concomitantly, the variety of aestheticising techniques perceivable in these dramas echo actual discussions as well as wishes for more debate and deliberation that are currently on the rise in our fast-paced age.

\section{Works Cited}

\section{Primary Literature}

Hare, David. Stuff Happens. London: Faber and Faber, 2006.

---. The Vertical Hour. London: Faber and Faber, 2008.

Ibsen, Henrik. A Doll's House. Trans. Kenneth McLeish. London: Nick Hern, 1994.

---. A Doll's House. Trans. Simon Stephens. London: Methuen, 2013.

Macmillan, Duncan. Lungs. London: Oberon, 2012.

Moore, D.C. The Empire. London: Methuen, 2010.

Penhall, Joe. Blue/Orange. The Methuen Drama Book of Twenty-First Century British Plays. Ed.

Aleks Sierz. London: Methuen, 2010. 1-118.

Plato. Phaedo. Trans. David Gallop. New York: Oxford UP, 1999. 
----. Ion. Plato: Statesman, Philebus, Ion. Trans. Harold North Fowler and W.R.M. Lamb.

Cambridge, MA: Harvard UP, 2006. 401-447.

Prebble, Lucy. Enron. London: Methuen, 2009.

Ravenhill, Mark. Plays One: Shopping and Fucking, Faust is Dead, Handbag, Some Explicit Polaroids. London: Methuen, 2001.

---. Mother Clap's Molly House. London: Methuen, 2001.

---. Candide. London: Bloomsbury, 2013.

Shaw, George Bernard. Man and Superman. London: Penguin, 2011.

--- . Pygmalion. London: Penguin, 2012.

\section{Secondary Literature}

Boles, William C. The Argumentative Theatre of Joe Penhall. Jefferson, NC: McFarland, 2011. Calhoun, Craig, Joseph Gerteis, James Moody et al. (eds.). Contemporary Sociological Theory. Malden, MA: Wiley-Blackwell, 2012.

Elster, Jon. “Introduction.” Deliberative Democracy. Ed. Jon Elster. Cambridge: CUP, 1998. 1-18.

Fearon, James D. “Deliberation as Discussion.” Deliberative Democracy. Ed. Jon Elster. Cambridge: CUP, 1998. 44-68.

Habermas, Jürgen. The Theory of Communicative Action. Vol. 1: Reason and the Rationalization of Society; Vol. 2: Lifeworld and System: A Critique of Functionalist Reason. Trans. Thomas McCarthy. Boston: Beacon Press, 1985.

---. The Philosophical Discourse of Modernity: Twelve Lectures. Cambridge, MA: MIT Press, 1990.

---. Between Facts and Norms: Contributions to a Discourse Theory of Law and Democracy. Cambridge, MA: MIT Press, 1996.

Kritzer, Amelia Howe. Political Theatre in Post-Thatcher Britain: New Writing, 1995-2005. Basingstoke: Palgrave Macmillan, 2008.

Lanchester, John. Whoops! Why Everyone Owes Everyone and No One Can Pay. London: Allen Lane, 2010.

McDowell, Linda. "Making a Drama out of a Crisis: Representing Financial Failures, or a Tragedy in Five Acts." Transactions of the Institute of British Geographers, New Series 36.2 (2011): 193-205.

0'Grady, Stephen. The New Kingmakers: How Developers Conquered the World. Beijing/Cambridge, MA: O'Reilly, 2013.

Puchner, Martin. The Drama of Ideas: Platonic Provocations in Theater and Philosophy. New York: Oxford UP, 2010.

Rubik, Margarete. “Joe Penhall.” The Methuen Drama Guide to Contemporary British Playwrights. Eds. Martin Middeke, Peter Paul Schnierer and Aleks Sierz. 363-382.

Sandel, Michael J. Justice: What's The Right Thing To Do? New York: Farrar, Straus and Giroux, 2009.

---. What Money Can't Buy: The Moral Limits of Markets. London: Allen Lane, 2012.

Sierz, Aleks. In-Yer-Face Theatre: British Drama Today. London: Faber and Faber, 2000.

---. Rewriting the Nation: British Theatre Today. London: Methuen, 2011.

Spencer, Charles. Rev. of Enron, by Lucy Prebble. Minerva Theatre, Chichester. Telegraph 23 July 2009. 27 Oct. 2013 <http://www.telegraph.co.uk/journalists/charles-spencer/5893217/ Enron-at-Minerva-Theatre-in-Chichester-review.html>. 